\title{
TRADISI PEMBUATAN TEMBIKAR DI DESA LAKARINTA, SULAWESI TENGGARA
}

\author{
(The Tradition of Pottery-Making in Lakarinta Village, Southeast Sulawesi)
}

\author{
Yanirsa Abigael Sendana \\ Balai Arkeologi Papua \\ J1. Isele, Kampung Waena, Distrik Heram, Kota Jayapura, Papua 99358 \\ Pos-el : yaniabigael@gmail.com.
}

\begin{tabular}{|c|c|}
\hline INFO ARTIKEL & ABSTRACT \\
\hline $\begin{array}{l}\text { Histori Artikel } \\
\text { Diterima : } 10 \text { Maret } 2020 \\
\text { Direvisi : } 11 \text { Mei } 2020 \\
\text { Disetujui : } 23 \text { Juni } 2020\end{array}$ & $\begin{array}{l}\text { The tradition of pottery-making is a prehistoric activity, which } \\
\text { can still be found until today. One area that still carries out such } \\
\text { tradition is Lakarinta village in Southeast Sulawesi. The purpose } \\
\text { of this study is to determine the traditional techniques of pottery- } \\
\text { making in Lakarinta village. The method used in this research }\end{array}$ \\
\hline $\begin{array}{l}\text { Keywords: } \\
\text { Lakarinta pottery, } \\
\text { paddle-anvil tradition, } \\
\text { cultural sustainability }\end{array}$ & $\begin{array}{l}\text { was complete participation with an ethnoarchaeological } \\
\text { approach, and data collection by interviews. Results showed that } \\
\text { pottery-making in Lakarinta village used paddle-anvil technique } \\
\text { to form vessels, and incised and impressed technique to make } \\
\text { decoration. The tools used for pottery-making were } \\
\text { kontumombaka, kadopi, kapepe, kalairo, poaro. Academically, } \\
\text { this research is expected to provide additional knowledge related } \\
\text { to the tradition of pottery-making in the Lakarinta village. } \\
\text { Practically, this research is expected to help the public to publish } \\
\text { the tradition of pottery-making in Lakarinta Village, which was } \\
\text { passed down by ancestors and has been practiced to this day. }\end{array}$ \\
\hline
\end{tabular}

Tembikar Lakarinta, tradisi tatap-pelandas, keberlangsungan budaya

\begin{abstract}
ABSTRAK
Tradisi pembuatan tembikar merupakan aktivitas prasejarah yang hingga saat ini masih dapat dijumpai. Salah satu wilayah yang masih melakukan tradisi ini adalah desa Lakarinta di Sulawesi Tenggara. Tujuan dari penelitian ini adalah untuk mengetahui teknik tradisional pembuatan tembikar di Desa Lakarinta. Metode yang digunakan dalam penelitian ini yaitu berpartisipasi penuh (complete participation) dengan pendekatan etnoarkeologi, serta melakukan pengumpulan data melalui wawancara. Hasil penelitian menunjukkan bahwa pembuatan tembikar di Desa Lakarinta menggunakan teknik tatap-pelandas untuk membentuk tembikar, serta teknik gores dan tekan untuk membuat hiasan. Alat-alat yang digunakan untuk membuat tembikar, yaitu kontumombaka, kadopi, kapepe, kalairo, poaro. Secara akademis, penelitian ini diharapkan memberi tambahan ilmu terkait tradisi pembuatan tembikar di desa Lakarinta. Secara praktis, penelitian ini diharapkan membantu masyarakat untuk mempublikasikan tradisi pembuatan tembikar di Desa Lakarinta yang diturunkan oleh nenek moyang dan masih berlanjut hingga saat ini.
\end{abstract}




\section{PENDAHULUAN}

Di Indonesia masih terlihat tandatanda bertahannya tradisi prasejarah sampai jauh memasuki masa sejarah, bahkan hingga saat ini (Soejono dkk, 2010: 433). Menurut Kamus Besar Bahasa Indonesia (KBBI) tradisi merupakan adat kebiasaan turun temurun (dari nenek moyang) yang masih dijalankan dalam masyarakat. Aktivitas yang berkembang pada masa prasejarah di antaranya adalah pembuatan perhiasan, termasuk manikmanik, dan pembuatan tembikar. Tembikar adalah benda dari tanah liat yang dibakar pada suhu pembakaran $350^{\circ} \mathrm{C}-1000^{\circ} \mathrm{C}$. Benda jenis ini bersifat menyerap dan dapat ditembus oleh air, karena memiliki permeabilitas yang relatif sedang sampai tinggi, dan berpori banyak. Bahan dasar biasanya dicampur dengan bahan lain sebagai temper, seperti pasir, pecahan kerang, potongan sekam padi, dan hancuran tembikar yang tidak dipakai (grog) (McKinnon, 1991: 2).

Tradisi tembikar merupakan tradisi yang termasuk tua dalam perkembangan kebudayaan manusia. Berdasarkan beberapa kajian sebelumnya, tembikar telah dikenal sejak zaman bercocok tanam. Zaman itu sangat penting dalam sejarah perkembangan dan peradaban masyarakat. Hal ini ditunjukkan dengan kemampuan menghasilkan teknologi untuk memenuhi keperluan sehari-hari, salah satunya tembikar (Soejono dkk, 2010: 206). Manusia mulai memikirkan kebutuhan akan persediaan makanan untuk dikonsumsi dalam pada jangka waktu yang panjang. Sejak saat itu tembikar menjadi salah satu perlengkapan kehidupan manusia yang penting, terutama dari segi kegunaannya. Tembikar relatif tahan air dan tahan panas api, sehingga bisa dipakai untuk berbagai macam tempat penyimpanan dan alat untuk keperluan masak-memasak (Soegondho, 1995: 1).

Secara garis besar, tembikar memiliki dua fungsi yaitu utilitarian (untuk kehidupan sehari-hari) dan ceremonial (untuk keperluan upacara). Fungsi semacam itu diduga berlaku sejak masa prasejarah hingga masa kini (Soegondo, 1995: 4). Terkait dengan fungsi, tembikar merupakan benda yang memiliki fungsi serta arti penting dalam kehidupan manusia, baik dalam kehidupan sosial ekonomi maupun kehidupan religious. Di dalam 
kehidupan religius suatu masyarakat tembikar berfungsi sebagai bekal kubur (grave goods) atau sebagai wadah kubur yang disebut tempayan kubur (burial urn) (Soegondo, 1995: 1).

Ada beberapa wilayah di Indonesia yang masih melakukan tradisi pembuatan tembikar tradisional yaitu tembikar di Trenggalek ${ }^{1}$ (Suroto, 2017: 22-236) Jawa Timur, di Mansinam ${ }^{2}$ Papua (Fairyo, 2009: 93-99), di Lipu Katobengke (Kabupaten Buton; Syahdat, 2014: 40) serta Kabupaten Muna (Kosasih, 1986 dan 1989) di Sulawesi Tenggara, dan sebagainya. Penelitian gua-gua prasejarah di Sulawesi Tenggara telah dilakukan oleh Balai Arkeologi (1997-2006-2008) Makassar, E.A Kosasih (1986 dan 1989) dan mahasiswa Arkeologi Universitas Halu Oleo. Penelitian tersebut menjelaskan bahwa adanya pemanfaatan pada gua-gua tersebut oleh manusia masa lalu yang sudah berlangsung sejak masa prasejarah hingga memasuki masa sejarah, baik sebagai tempat hunian, ritual maupun

\footnotetext{
${ }^{1}$ Menggunakan dua teknik dalam proses pembentukkan gerabah yaitu teknik roda putar dan tatap-plandas. Pembakaran dilakukan dalan tobong (tungku pembakaran terbuka berbentuk bulat).
}

lokasi penguburan (Hakim dkk, 2011: 1). Salah satu hasil temuan dari penelitian tersebut adalah fragmen tembikar, baik yang temukan di permukaan maupun yang terdeposit di dalam tanah. Fragmen tembikar hasil ekskavasi Kosasih 1986 di Gua Kobori, Pulau Muna merupakan fragmen tembikar yang memiliki ragam hias sederhana (geometris yang terdiri dari motif tumpal bersilang, garis, cungkil dan jala (Kosasih, 1989: 21). Selain itu hasil penelitian fragmen tembikar di Konawesi Utara berupa periuk, tempayan dan mangkok (Sendana, 2017: 59-61). Ada yang difungsikan sebagai bekal kubur ada juga yang digunakan sebagai wadah kubur. Tembikar tersebut memiliki banyak ragam hias yang berbeda-beda. Ragam hias tersebut berbentuk geometris (segitiga, garis horizontal-vertikal, bulatan, persegi empat, titik dll). Fragmen tembikar dari gua-gua prasejarah di Sulawesi Tenggara dan Kalumpang Sulawesi Barat memiliki ciri tembikar tradisi Sa-Huynh-

\footnotetext{
${ }^{2}$ Menggunakan dua teknik yaitu, roda putar dan tatap-pelandas dengan pembakaran terbuka yaitu diatur di atas tumpukan kayu bakar kemudian ditutup dengan daun kelapa atau daun sagu.
} 
Kalanay. Hal ini dapat dilihat dari bentuk wadah, ragam hias dan teknik tatap-pelandas yang digunakan (Solheim II, 1972: 17-21).

Khusus untuk Kabupaten Muna, terdapat sekumpulan masyarakat yang masih melanjutkan tradisi pembuatan tembikar dengan alat-alat yang sederhana tepat nya di Desa Lakarinta. Masyarakat tersebut merupakan Suku Labora yang berimigrasi dari Pulau Buton. Suku Labora merupakan suku yang terkenal sebagai pengrajin tembikar. Mereka merupakan penduduk tertua di Pulau Muna yang bermukim di Kampung Lama (Yabu, tanpa tahun: 7). Suku ini pun menyebar ke beberapa lokasi salah satunya di Desa Lakarinta. Sebelumnya, pada tahun 1989 Kosasih telah melakukan penelitian terkait tembikar di Kampung lama sebelum masyarakat tersebut terpecah ke beberapa wilayah. Hingga saat ini penduduk di desa Lakarinta masih melakukan pembuatan tembikar.

Berangkat dari latar belakang di atas maka rumusan masalahnya adalah "Bagaimana teknologi yang digunakan dalam pembuatan tembikar yang terdapat di desa Lakarinta, Kabupaten Muna?". Tujuan dari penelitian ini adalah ingin mengetahui teknologi yang berkaitan dengan teknik pengerjaan serta bahan yang digunakan dalam pembuatan tembikar di Desa Lakarinta, Kabupaten Muna.

\section{METODE PENELITIAN}

Lokasi penelitian berada di Desa Lakarinta, Kecamatan Lohia, Kabupaten Muna, Sulawesi Tenggara dengan titik koordinat $04^{\circ} 55^{\prime} 13.41^{\prime \prime}$ Lintang Selatan (LS) 12244'39.83” Bujur Timur (BT).

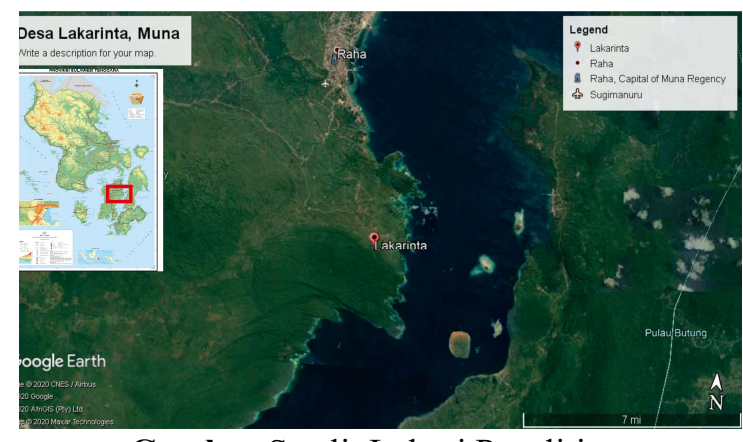

Gambar Satelit Lokasi Penelitian (Sumber: Google Earth 2020, diunduh 10 Juni 2020 pkl 09.30 WIT )

Metode yang digunakan adalah metode penelitian kualitatif yang bersifat deskriptif yaitu upaya memberikan penggambaran proses budaya atau fenomena yang terdapat pada sekelompok masyarakat. Pendekatan yang digunakan dalam penelitian ini adalah etnoarkeologi. Etnoarkeologi memperlajari bagaimana 
masyarakat kontemporer menggunakan budaya material dari perspektif arkeologis dengan mengkorelasikan aktivitas masa kini agar dapat memahami perilaku pada sekelompok masyarakat (Grant, 2002: 102). Penelitian etnoarkeologi meneliti aspek perilaku sosial budaya kontemporer dari perspektif arkeologi. Peneliti etnoarkeologi harus berusaha untuk mendefinisikan hubungan antara perilaku dan budaya material yang tidak dieksplorasi oleh ahli etnologi, dan untuk memastikan bagaimana ciri-ciri tertentu dari perilaku yang dapat diamati dari tinggalan-tinggalan yang ditemukan oleh ahli arkeologi (Kramer, 1979: 1). Pada tataran interpretasi dilakukan analogi etnografis. Analogi digunakan untuk menjawab permasalahan yang berkaitan dengan teknologi (fungsi-buat) dan penggunaan (fungsi-pakai). Prinsip analogi ini didasarkan pada asumsi bahwa teknologi pembuatan dan pemakaian tembikar di masa lalu tidak mempunyai perbedaan dengan masa sekarang (McKinnon, 1991: 35).

Teknik pengumpulan data penelitian meliputi observasi dan

3 Tanah liat primer adalah tanah liat yang terdeposit di tempat bebatuan induknya. Oleh karena itu untuk bisa memperolehnya biasanya wawancara. Observasi dilakukan dengan mengamati objek-objek yang akan diteliti. Pengamatan ini akan menggunakan pengamatan terlibat secara langsung dan berpartisipasi penuh (complete participation) yaitu masuk secara total kedalam kelompok yang diamati, terlibat dan mengalami impresi yang sama (Hasana, 2016: 30) guna lebih mengetahui tahapan proses pembuatan tembikar pada di desa Lakarinta. Teknik wawancara yang dilakukan dalam penelitian ini adalah wawancara bebas yaitu wawancara yang tidak menggunakan pedomana wawancara, sehingga tanya jawab yang terjadi tidak terfokus pada satu arah (Sandjaja, 2006: 145).

\section{PEMBAHASAN}

Proses pembuatan tembikar di desa Lakarinta meliputi persiapan bahan, proses pembentukan, proses pengeringan dan proses pembakaran.

\section{Persiapan Bahan}

Bahan tanah liat yang digunakan oleh masyarakat Lakarinta adalah tanah liat primer $^{3}$. Bahan tersebut diperoleh dari tangan pertama 
(masyarakat penambang), diambil dari Kolese yang lokasinya tidak jauh dari pantai. Tanah liat Kolese berwarna abu-abu. Untuk mencapai lokasi penambangan dari desa Lakarinta ke Kolese dibutuhkan waktu sekitar dua jam perjalanan mengggunakan perahu (katinting). Namun demikian, saat ini pengrajin tembikar dapat membeli tanah liat secara langsung dari para penambang dengan harga $\mathrm{Rp}$. 10.000,00 untuk satu karung. Alasan mereka membeli, karena untuk sampai di Kolese dan mengambil sendiri tanah liat tersebut, si pembeli harus harus menguras kantung sebanyak Rp. 200.000,00.

Bahan utama tanah liat tersebut kemudian direndam dengan air agar lunak dan mudah dibentuk. Setelah direndam, tahap selanjutnya adalah mengambil bahan campuran, yaitu pasir. Pasir yang digunakan adalah pasir pantai yang putih, bersih dan halus. Pengrajin harus menempuh perjalanan dengan berjalan kaki sekitar satu kilometer (1 $\mathrm{km})$ untuk memperoleh pasir tersebut.

batuan induknya adalah granit), sifatnya tidak plastis (tidak lentur) (McKinnon, 1991: 7).
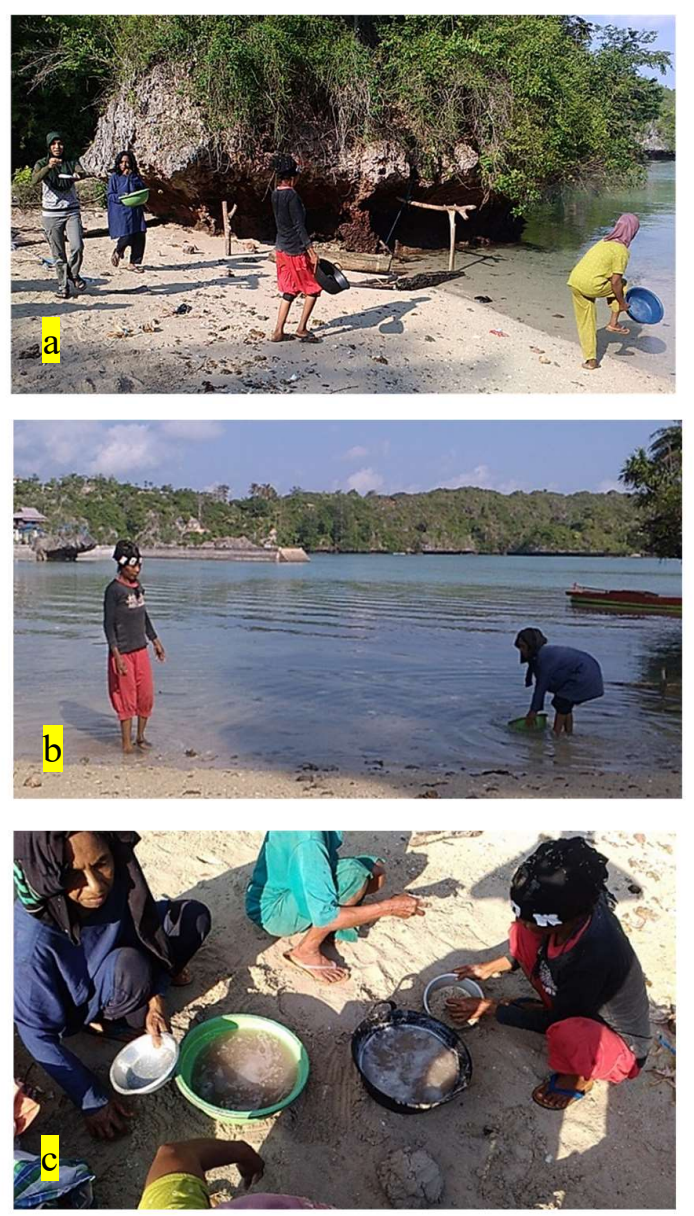

Gambar 1. (a) Persiapan Pengambilan Pasir, (b) Proses Pengambilan Pasir, (c) Proses Penyaringan. (Dokumentasi: Penulis)

Setelah sampai di lokasi pengambilan bahan campuran, Ina dan pengrajin lainnya mulai menyusun wadah berukuran sedang (baskom) guna diisi pasir (Gambar. 1 (a)). Pasir yang digunakan adalah pasir yang terendam di dalam air. Pasir tersebut kemudian disaring (Gambar. 1 (c)) 
sehingga mendapatkan butiran yang paling halus agar dapat digunakan sebagai bahan campuran.

Setelah disaring, pasir kemudian ditiriskan dari sisa-sisa air laut dan didiamkan. Setelah itu, bahan campuran pasir dikeringkan dengan cara dijemur (Gambar. 2 (b)). Pasir harus dipastikan dalam keadaan yang kering sehingga pada saat proses pencampuran, semua bahan dapat menyatu dengan baik. Menurut Ina Pera, pasir yang tidak kering akan mempengaruhi kualitas tembikar yang dihasilkan; pada permukaannya bagian luar tembikar akan timbul benjolan-bejolan (tidak rata), bahkan mudah retak saat pembentukan.

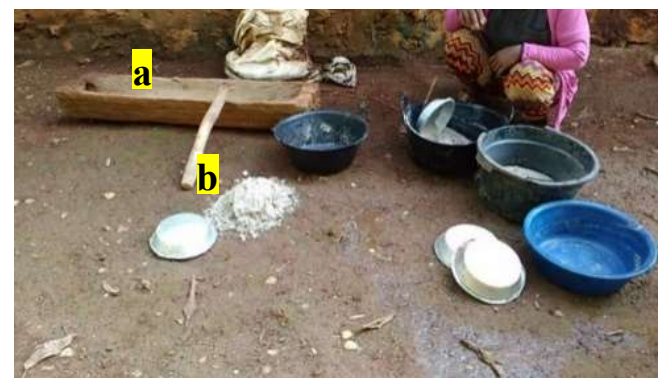

Gambar. 2 (a) Katumbu (lesung), tempat untuk mencampur tanah liat dan pasir), (b) Pasir yang dijemur. (Dokumentasi: Penulis)

Tahap selanjutnya adalah pencampuran tanah liat dengan campuran pasir putih. Hal yang pertama dilakukan adalah mengolesi katumbu (lesung) dengan sedikit pasir dengan tujuan agar tanah liat yang akan diletakan di dalam lesung tidak melekat. Selanjutnya tanah liat dimasukkan ke dalam katumbu (Gambar. 3 (a)) sebanyak tiga genggam dan segenggam pasir. Dalam proses pencampuran, takaran pasir lebih sedikit dibandingkan dengan takaran tanah liat. Menurut Ina Pera, jika takaran pasirnya lebih banyak atau sama, maka tekstur permukaan tembikar akan kasar. Selain itu, jika takaran adonan sama maka adonan akan mengeras dan akan sulit untuk dibentuk serta mudah retak saat dijemur. Cara mencampur kedua bahan tersebut adalah dengan cara ditumbuk sampai benar-benar tercampur dengan rata (Gambar. 3 (b)).
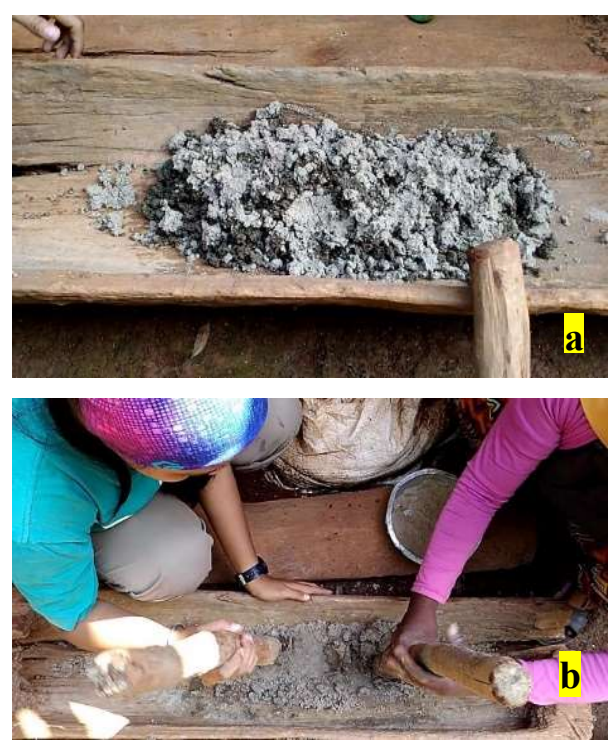

Gambar. 3 Bahan (pasir dan tanah liat) (a); Proses Pencampuran Bahan (ditumbuk) (b) (Dokumentasi: Ersa Dwi Ryanto) 
Proses pencampuran ini terus dilakukan sampai tanah liat dan pasir benar-benar tercampur dengan rata. Pada saat proses pencampuran ini ada beberapa hal yang harus diperhatikan, yaitu tidak ada kotoran-kotoran seperti daun, ranting atau batu yang melekat pada bahan yang sedang dicampur karena akan merusak kualitas dari tembikar yang akan dihasilkan. Proses pencampuran dilakukan selama 25 menit.

\section{Proses Pembentukan}

Teknik tatap pelandas adalah teknik yang dilakukan dengan cara memukul dinding tembikar secara perlahan dengan pemukul panjang terbuat dari kayu dan bambu yang berbentuk pipih (paddle), sementara pada bagian dalamnya ditahan oleh pelandas batu (anvil), yang berbentuk bulat (McKnnon, 1991: 22). Rigger (1972 dalam Pojoh 1981) menerangkan bahwa bentuk cembung dari sebuah batu yang dibentuk bulat dan sedikit pipih merupakan bagian terpenting dari sebuah pelandas karena kecembungan inilah yang menentukan bentuk dinding tembikar. Alat yang digunakan pada proses pembentukan tembikar di desa
Lakarinta sangat sederhana seperti yang telah dijelaskan sebelumnya (tatappelandas).

Masyarakat setempat menyebut alatalat tersebut dengan bahasa lokal. Alatalat yang digunakan antara lain:

a) Kontumombaka (Gambar 4. (a)) (pelandas) yaitu batu enak atau batu gepeng, yang dibuat dari batu gamping kemudian dibentuk bulat dan pipih (sedikit cembung). Bahan yang digunakan diambil dari lingkungan sekitar tempat tinggal. Masyarakat menyebut dengan batu enak karena menggunakan alat tersebut nyaman (enak). Selain itu, kontumombaka juga berfungsi untuk menstabilkan permukaan bagian dalam.

b) Kadopi (Gambar 4. (b)) atau penghalus (bagian luar) dibuat dari kayu ghefi yang digunakan pada tahap akhir, untuk menghaluskan permukaan luar tembikar.

c) Kapepe (Gambar 4. (c)) atau pemukul bibir dibuat buat dari 

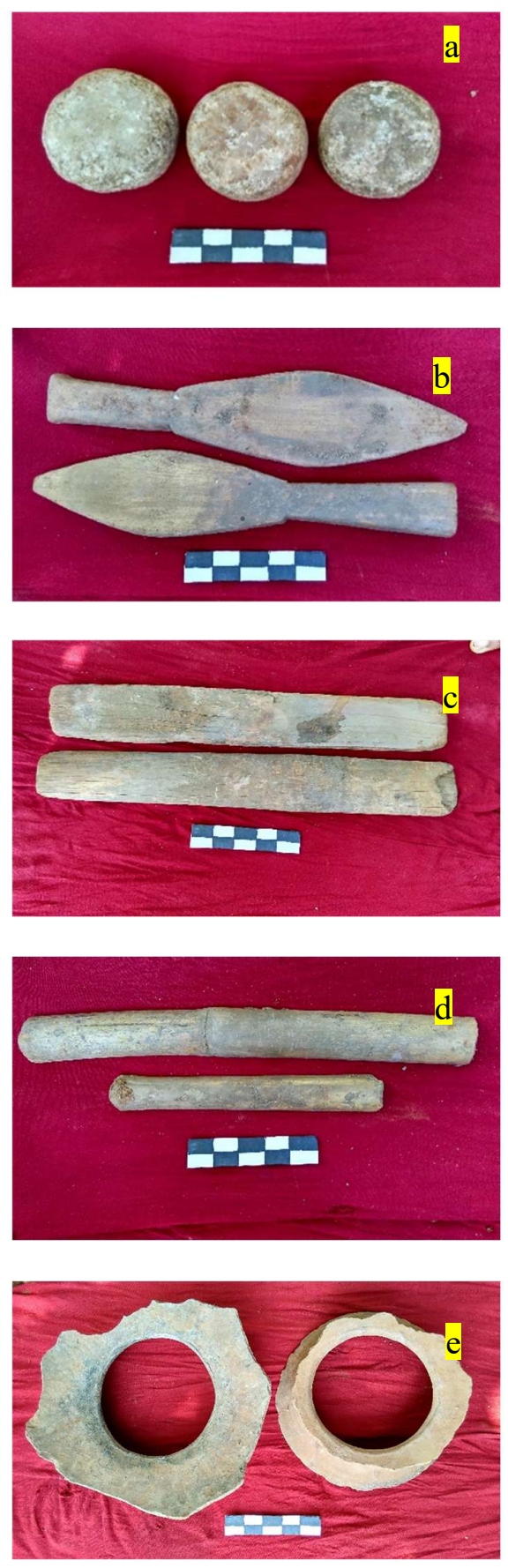

Gambar 4. Alat-Alat pembuatan tembikar. Kontumombaka (a); Kadopi (b); Kapepe (c); Kalorio (d); Poaro (e) (Dokumentasi: Ersa Dwi Ryanto) kayu ghefi dan digunakan untuk membuat bagian bibir tembikar menjadi rata.

d) Kalario (Gambar 4. (d)) atau penghalus berukuran kecil dan pembentuk leher berukuran besar dibuat dari bambu yang dibelah menjadi dua.

e) Poaro (Gambar 4. (e)) yaitu dudukan tembikar merupakan fragmen tepian utuh melingkar. Poaro digunakan sebagai dudukan tembikar yang akan dijemur.

Pada proses pembentukan, tanah liat yang telah dibentuk lonjong kemudian dibentuk menjadi suatu wadah. Cara untuk membentuk calon wadah adalah memukul dan memijat salah satu bagian ujung lonjongan menggunakan kontumombaka, sehingga membentuk lubang. Setelah itu meratakan bagian luar permukaan tembikar. Alat yang digunakan adalah kontumombaka dan kapepe. Kontumombaka diposisikan pada bagian dalam dan berfungsi untuk menahan pukulan dari luar menggunakan kapepe seperti tampak pada pada Gambar 5 dan Gambar 6 di bawah. 


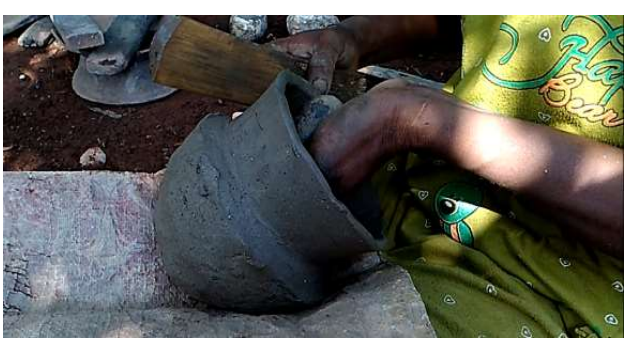

Gambar. 5 Proses perataan pada bagian luar (badan) menggunakan kontumombaka (Foto 4.

(a)) dan kapepe (Gambar 4. (c))

(Dokumentasi: Ersa Dwi Ryanto)

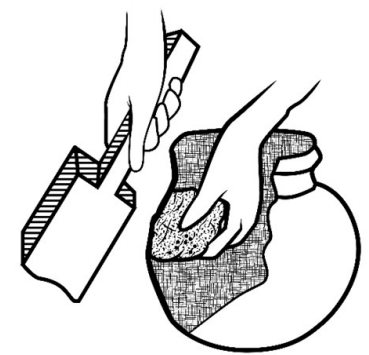

Gambar 6. Teknik Tatap-Pelandas (Sumber: Hodges, 1964, dalam McKinnon 1991; dimodifikasi oleh Apridio Katili)
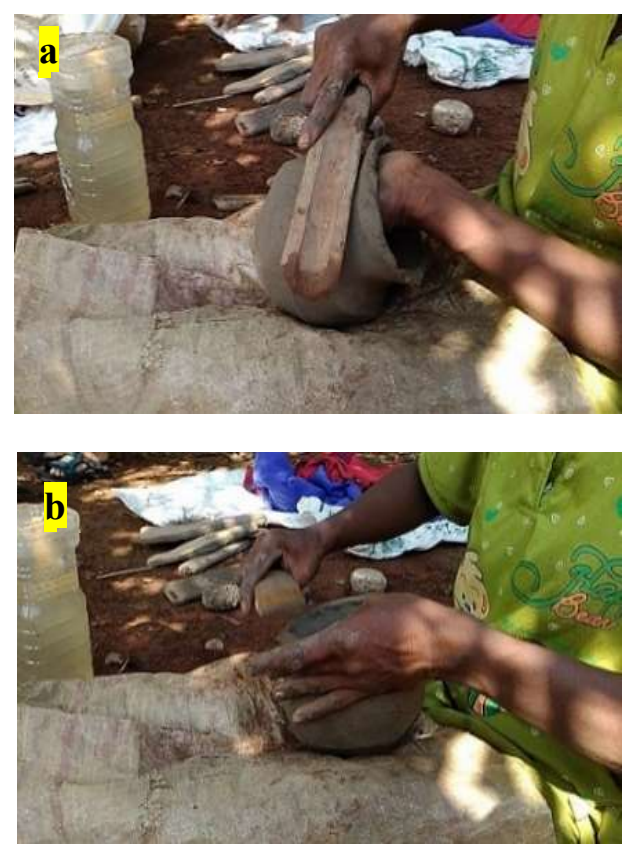

Gambar. 7 Proses pembuatan (a); bahu dan bibir (b)

(Dokumentasi: Ersa Dwi Ryanto)
Setelah meratakan permukaan tembikar, langkah selanjutnya adalah membuat bahunya. Alat kayu yang digunakan untuk membuat bahu adalah kalairo yang berukuran $13 \mathrm{~cm}$ dengan cara memukul bagian bahu sembari diputar agar lekungannya rata. Lekungan pada bagian bahu tembikar dibuat menggunakan alat kalairo (Gambar. 7a). Setiap proses pembentukan bahu, kalairo selalu diolesi air agar tanah liat tidak melekat pada alat dan membuat tanah liat tetap mudah dibentuk. Setelah bahu dibentuk, langkah selanjutnya adalah meratakan bibir tembikar. Alat yang digunakan adalah kapepe dengan cara memukul dari arah vertikal (dari atas) (Gambar. 7b). Cara tersebut akan membuat rata bagian bibir tembikar sehingga terlihat rapi. Setelah badan, bahu, dan bibir terbentuk. Langkah selanjutnya adalah penghalusan permukaan luar tembikar.

Alat kayu yang digunakan untuk menghaluskan permukaan luar menggunakan kalario (Gambar. 7b) dan kadopi (Gambar. 4.(b)). Selain dari kedua alat tersebut untuk menghaluskan pada bagian tepian juga bisa menggunakan jari jempol (Gambar. 7a). 
Dalam proses ini, bagian permukaan termbikar harus selalu basah atau tersentuh dengan air. Hal ini membantu untuk mempercepat proses penghalusan.
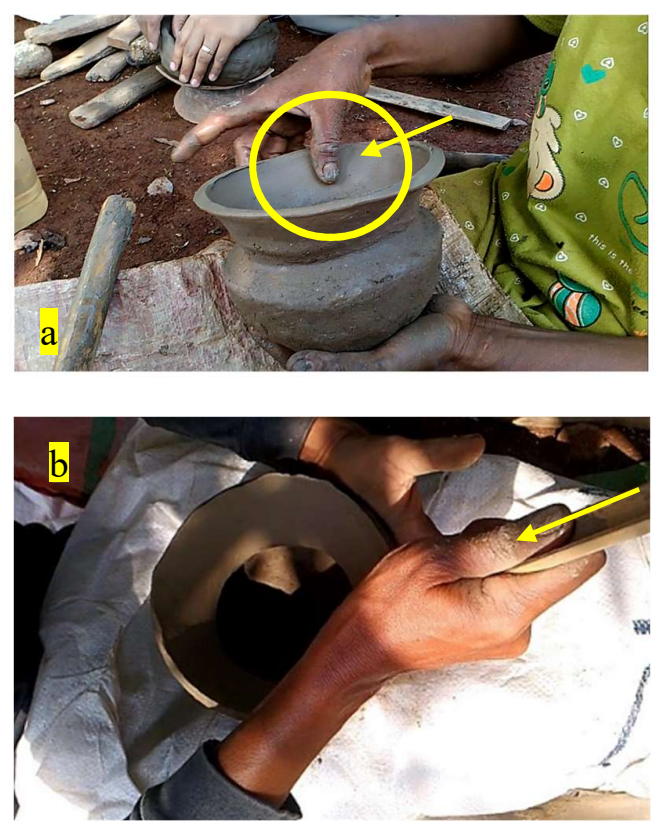

Gambar. 8 Proses penghalusan menggunakan tangan (jari jempol) (a); Menggunakan kalario (Dokumentasi: Ersa Dwi Ryanto)

Tahap selanjutnya adalah pemberian hiasan pada tembikar. Ragam hias yang digunakan pada bagian permukaan adalah geometri berbentuk segitiga (Gambar 9 (a)), dan garis melengkung (Gambar 9. (b)) dan gerigi (9. (c)).
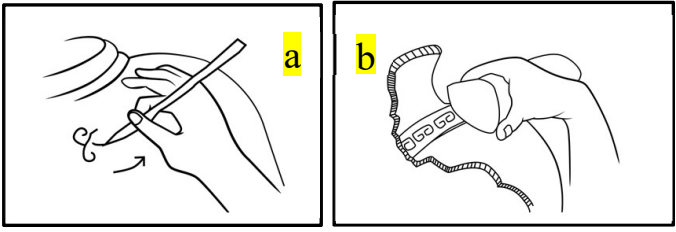

Gambar 11 Teknik Gores (a); Teknik Tekan (b) (Sumber: Wibisono 1981 dalam McKinnon 1991; dimodifikasi oleh Apridio Katili Katili)
Teknik yang digunakan untuk membuat hiasan tersebut adalah gores (Gambar 11. (a)) dan tekan (Gambar 11. (b)). Bagian permukaan digores dengan menggunakan ujung pisau dan ditekan menggunakan tepian dari kayu kapepe.
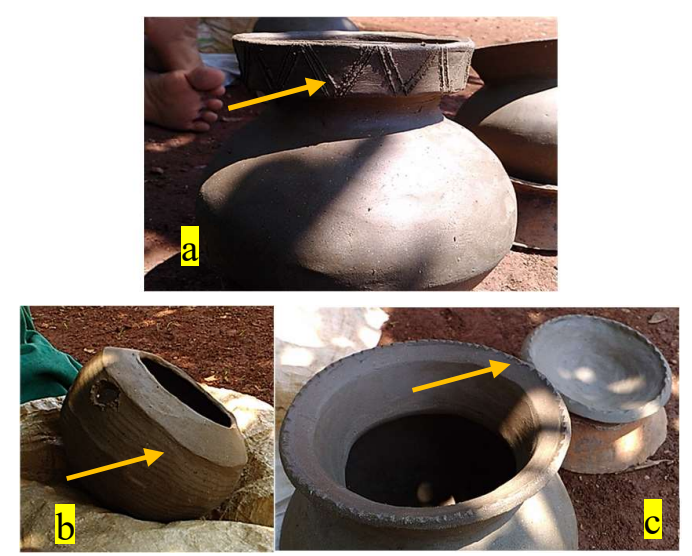

Gambar. 9 Ragam hias pada tembikar. Segitiga (a); Garis Melengkung (b); Gerigi (c) (Dokumentasi: Ersa Dwi Ryanto)

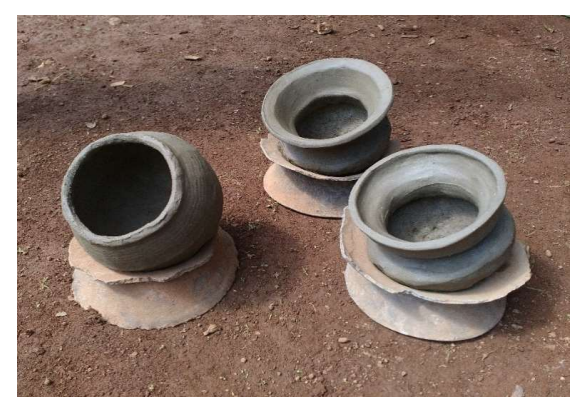

Gambar. 10 Pengeringan (dijemur) (Dokumentasi: Ersa Dwi Ryanto)

\section{Proses Pengeringan}

Proses ini dilakukan agar kadar air yang terkandung di dalam adonan tembikar hilang dan agar tekstur adonan tembikar sedikit mengeras sehingga memudahkan proses pembakaran. Tembikar yang baru saja dibentuk 
kemudian dijemur atau diletakkan langsung di bawah sinar matahari (Gambar 10). Jika cuaca tidak mendukung, karena mendung dan

hujan, maka peroses pengeringan akan berlangsung lama. Jadi, dalam pembuatan gerabah sangat penting memperhatikan cuaca.

\section{Proses Pembakaran}

Tembikar dibakar pada suhu antara $350^{\circ} \mathrm{C}$ dan $1000^{\circ} \mathrm{C}$ (Rangkuti dkk, 2008: 1). Secara umum terdapat dua cara pembakaran keramik yaitu pembakaran dengan suhu rendah yaitu dilakukan di tempat terbuka dan pembakaran suhu tinggi yaitu menggunakan tungku pembakaran yang tertutup (McKinnon, 1991: 20)

Berdasarkan observasi, teknik pembakaran yang digunakan oleh masyarakat di desa Lakarinta adalah teknik dengan suhu rendah, yaitu pembakaran terbuka (open firing) (Gambar. 12). Pembakaran terbuka tersebut dilakukan di dekat halaman rumah Ina Pera. Teknik pembakaran ini sering disebut juga domestic firing (McKinnon, 1991: 20), yaitu cara pembakaran di mana tembikar disusun di atas permukaan tanah, kemudian ditutupi dengan bahan yang mudah terbakar berupa ranting kering, kulit buah kapuk, dan daun pisang kering (Gambar 13a dan 13b). Pengendalian suhu pembakaran serta lama pembakaran ditentukan oleh angin, sehingga pembakaran harus selalu dipantau agar gerabah yang dibakar hasilnya baik. Bahan bakar diperoleh di sekitar rumah Ina Pera.

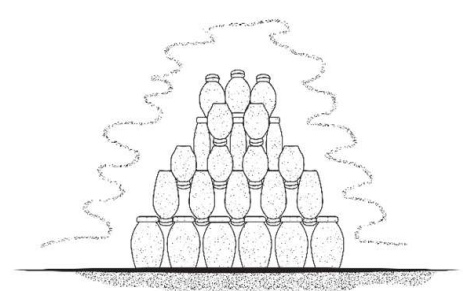

Gambar. 12 Pembakaran Terbuka (Sumber: Hogle 1974 dalam McKinnon 1991; dimodifikasi oleh Apridio Katili)
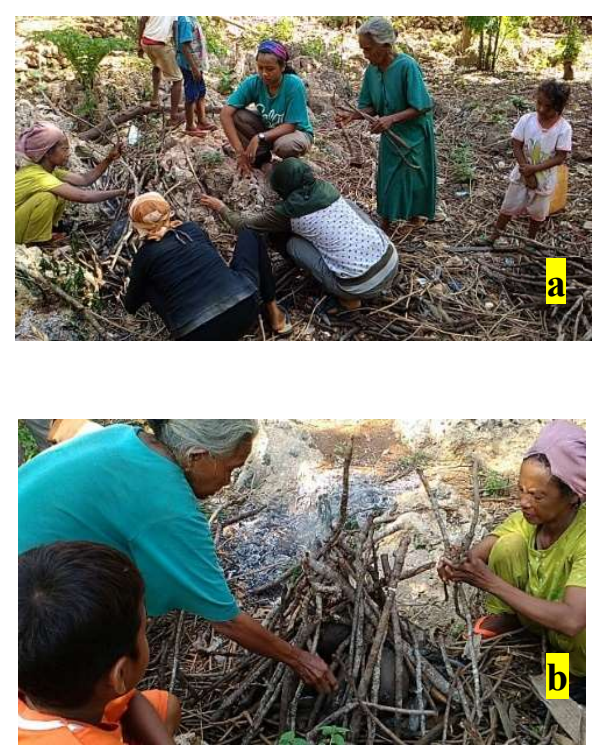

Gambar. 13a dan 13b. Proses Pembakaran (Dokumentasi: Ersa Dwi Ryanto) 


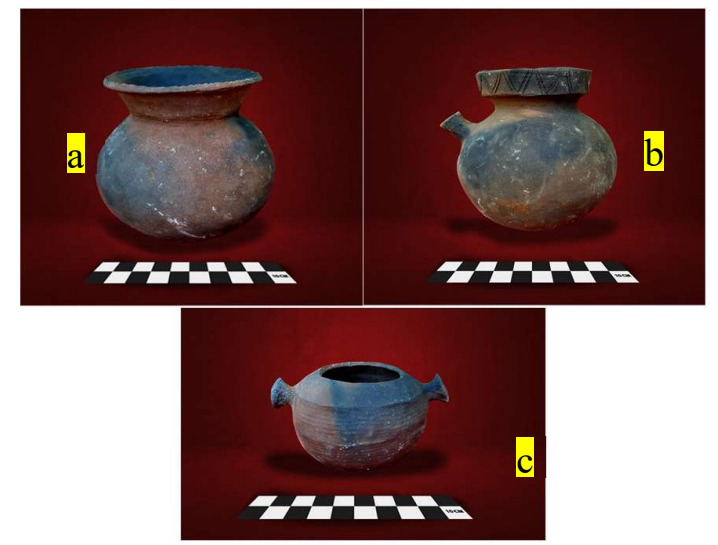

Gambar. 14 Balanga Berhias (a), Balanga Bertelinga (b) dan Kendi (c)

(Dokumentasi: Ersa Dwi Ryanto dimodifikasi oleh Apridio Katili)

Cara pembakarannya adalah daun pisang kering diletakkan di permukaan tanah terlebih dahulu, kemudian tembikar ditumpuk (Gambar. 13 (a)). Tahap selanjutnya kulit buah kapuk yang kering ditaburkan di atas tumpukkan tembikar, dan selanjutnya ditutup dengan tumpukan ranting kering. Ranting kering disusun seperti membuat api unggun, di mana kayu didirikan dan disandarkan pada tumpukan tembikar (Gambar. 13 (b)).

\section{Bentuk-Bentuk Tembikar di Desa}

\section{Lakarinta}

Bentuk-bentuk wadah yang dihasilkan oleh pengrajin tembikar di Desa

Lakarinta adalah sebagai berikut:

a) Balanga berhias (Gambar. 14 (a)), merupakan wadah berbentuk bulat

${ }^{4}$ Baca-baca merupakan salah satu upaya menghadirkan tokoh agama atau adat untuk membacakan doa-doa tertentu sebagai upaya menguncap yang bagian tepiannya berorientasi keluar (terbuka) berdiameter $6 \mathrm{~cm}$ yang berfungsi untuk keperluan rumah tangga seperti memasak atau tempat penyimpanan makanan. Selain itu, fungsi lainnya sebagai keperluan sakral atau bacabaca $^{4}$. Balanga ini memiliki ragam hias gerigi (Gambar. 9 (c)) di bagian bibirnya.

b) Balanga bertelinga (Gambar. 14 (b)), merupakan wadah berbentuk bulat yang bagian tepiannya berorientasi masuk ke dalam (tertutup) berdiameter $3,5 \mathrm{~cm}$ yang berfungsi khusus untuk keperluan rumah tangga seperti memasak. Telinga atau yang sering disebut dengan kupingan berfungsi sebagai pegangan. Balanga ini memiliki ragam hias geometris: garis melengkung (Gambar. 8 (b)) di bagian badannya.

c) Kendi (Gambar. $14 \quad$ (c)), merupakan wadah yag memiliki badan bulat, berleher sedikit panjang dan bermulut sempit memiliki cerat berdiameter $5,5 \mathrm{~cm}$

syukur, acara kematian maupun menolak bala. Ini adalah salah satu ritual yang bercorak animism (kepercayaan terhadap nenek moyang) (Rahmatang, 2016: 7-10). 
yang berfungsi sebagai tempat penyimpanan air minum. Kendi ini memiliki ragam hias geometris: segitiga (Gambar. 8 (a)).

Berdasarkan pengamatan terhadap pembuatan tembikar di Desa Lakarinta, Kecamatan Lohia, Kabupaten Muna, Sulawesi Tenggara, masyarakat lakarinta masih melakukan tradisi pembuatan tembikar yang sudah dikenal sejak zaman bercocok tanam. Hal ini dapat dilihat dari teknlogi pembutan tembikar tersebut. Terkait teknologi, penulis akan membandingkan dengan hasil penelitian yang dilakukan oleh Kosasih pada tahun 1989 terkait pembuatan tembikar oleh Suku Labora di Muna.

Bahan utama yang digunakan dalam pembuatan tembikar di Desa Lakarinta adalah tanah liat yang diperoleh dari penambang tanah liat yang berada di Kolose, sedangkan bahan campurannya yaitu pasir diambil dari pinggir pantai yang tidak jauh dari pemukiman. Masyarakat memanfaatkan bahan yang terdapat di lokasi pemukiman mereka. Alat yang digunakan sederhana terbuat dari kayu, batu gamping dan bambu. Teknik yang digunakan dalam pembentukan tembikar adala teknik tatap pelandas dan teknik penerapan ragam hias menggunakan teknik gores dan tekan. Bentuk tembikar yang dihasilkan oleh pengrajin di Desa Lakarinta berupa periuk dan kendi dengan ragam hias geometris (segitiga, garis horizontal) memiliki persamaan dengan fragmenfragmen tembikar yang ditemukan di situs arkeologi di Sulawesi Tenggara yang dilihat dari segi bentuk dan ragam hias nya. Hal ini menunjukan bahwa bentuk tembikar serta ragam hias yang dihasilkan oleh manusia masa lalu tidak memiliki perbedaan dengan tembikar yang dihasilkan pada masa kini.

Penelitian yang dilakukan Kosasih sedikit menyinggung tentang peran kaum pria dan wanita dalam proses pembuatan tembikar di mana kaum pria bertugas untuk mengambil bahan, membantu membuat adonan, membakar tembikar serta memasarkanya. Namun, dalam proses pembuatan tembikar di Desa Lakarinta seluruh kebutuhan dan pekerjaan dilakukan oleh kaum wanita. Hal ini kemungkinan terjadi karena pembuatan tembikar bukan prioritas dalam memenuhi kebutuhan ekonomi. Kaum 
laki-laki lebih fokus untuk menggarap pertanian serta peternakan yang lebih menghasilkan dan memenuhi kebutuhan ekonomi mereka. Kurangnya konsumen merupakan alasan utama mereka tidak intens memproduksi tembikar. Selain pembagian tugas dalam pembuatan, proses persiapan bahan campuran berbeda yaitu masyarakat Lakarinta menjemur pasir hingga kering agar dapat tercampur baik dengan bahan utama. Hal ini berbeda dengan sebelumnya yang membiarkan bahan campuran dalam kondisi lembab. Hal lain yang terkait dengan bahan yaitu perbandingan takaran yang dahulu $2: 1$ (2 genggam tanah liat dan 1 genggam pasir) menjadi 3:1 (2 genggam tanah liat dan 1 genggam pasir). Perubahan terjadi kemungkinan dari bahan campuran yang diperoleh dari tempat yang berbeda. Dapat dilihat dari tekstur atau juga besar butiran pasir yang digunakan. Terkait teknik pembuatan, teknik yang digunakan dalam pembuatan tembikar tidak dikolaborasikan dengan teknik lainnya, hanya menggunakan tatap pelandas. Hal yang sama pada ragam hias, pada dasarnya Suku Labora tidak memiliki maksud tertentu dalam penambahan ragam hias melainkan hanya sekedar menambah keindahan.

Selain perbedaan dari segi teknologi, perbedaan juga dapat dilihat dari segi fungsi yaitu tembikar saat ini difungsikan sebagai alat untuk memenuhi kebutuhan sehari-hari saja. Namun sesekali digunakan sebagai kelengkapan untuk acara baca-baca. Namun saat ini jumlah pemesanan maupun pemasaran di pasar tidak banyak bahkan terkadang tidak ada pemasukan samasekali. Hal ini disebabkan oleh perkembangan zaman dimana masyarakat telah beralih keperlengkapan yang lebih praktis serta bahan yang tidak mudah pecah seperti wadah plastik maupun aluminium.

Seiring berkembangnya zaman, produksi tembikar di desa Lakarinta menurun dan terkadang samasekali tidak memproduksi. Pengrajin tembikar di Desa Lakarinta berjumlah lima orang, yaitu Wa Ode Pera, Wania, Wa Abe, Wa Maliana dan Wa Aji. Mereka masih memiliki hubungan keluarga. Berdasarkan hasil wawancara yang dilakukan, pengrajin tersebut tidak ada satupun yang tahu tentang sejarah pembuatan tembikar yang turun temurun mereka lakukan. Mereka hanya mengetahui bahwa ini adalah 
tradisi yang diwariskan orang tua mereka. Salah satu informan, yang bernama Wa Ode Pera (67 tahun), telah membuat tembikar sejak berusia 12 tahun. Ibu dari Ina Pera ini masih hidup dan berusia sekitar seratus tahun lebih.

Dari beliaulah Ina Pera belajar pembuatan tembikar. Setiap harinya beliau selalu mengajak Ina pera mengambil bahan dan membuat tembikar. Kemudian, Ina Pera mewariskan kepada anak dan menantunya (empat pengrajin yang lain). Namun demikian, warisan tersebut berhenti di anak dan menantu. Saat diwawancarai, Ina mengatakan bahwa cucunya tidak mau belajar membuat tembikar karena kotor, seperti anak kecil dan sudah ketinggalan zaman.

\section{PENUTUP}

Pembuatan tembikar di Desa Lakarinta, di Sulawesi Tenggara, memperlihatkan tradisi prasejarah yang masih dipertahankan. Hal ini diperkuat dengan tinggalan arkeologi yang berupa fragmen tembikar serta gambar cadas yang menggambarkan aktivitas berburu dan bercocok tanam di beberapa gua di Sulawesi Tenggara. Pada masa itu, manusia mulai memikirkan peralatanperalatan yang dibutuhkan terutama wadah penyimpanan makanan atau sebagai keperluan ritual.

Berdasarkan hasil penelitian dapat disimpulkan bahwa teknologi pembuatan tembikar di desa Lakarinta menggunakan metode tatap-pelandas. Teknik ini merupakan teknik yang digunakan untuk membuat tembikar pada masa bercocok tanam. Pada masa tersebut, manusia telah mampu menciptakan teknologi-teknologi yang dapat memenuhi kebutuhan sehari-hari. Bahan yang digunakan bersumber dari alam atau lingkungan, di mana mereka bermukim. Alat-alat yang digunakan oleh pengarajin tembikar di Desa Lakarinta merupakan alat yang bersumber dari alam dan lingkungan sekitar yang kemudian dimodifikasi sesuai dengan kebutuhan. Alat-alat tersebut adalah kotumombaka (batu pelandas dibuat dari batu gamping), kadopi (tatap-kayu gefy), kapepe (tatapkayu gefy), kalario (tatap-bambu), dan poaro. Masyarakat Lakarinta menyebut alat-alat pelandas menggunakan bahasa lokal.

Jenis-jenis tembikar yang dihasilkan berupa balanga (periuk) dan kendi. 
Jenis tembikar ini bercirikan tembikar masalalu yang dulu difungsikan sebagai alat rumah tangga serta kelengkapan ritual. Bentuk tembikar yang diproduksi sampai sekarang mengikuti selera pasar atau konsumen. Semakin berkembangnya zaman, minat konsumen terhadap tembikar mulai menurun karena konsumen beralih ke wadah yang lebih praktis dan dapat bertahan lama (tidak mudah pecah). Saat ini tembikar di desa Lakarinta digunakan sebagai alat perlengkapan rumah tangga dan terkadang digunakan sebagai perlengkapan ritual baca-baca. Ragam hias yang digunakan pada tembikar tersebut merupakan ragam hias geometris yang notabene digunakan juga pada tembikar di masa lalu. Namun, masyarakat tidak memiliki maksud lain selain menambah keindahan pada tembikar.

Terkait dengan proses pembuatan tembikar di Desa Lakarinta, terdapat perbedaan dilihat dari pembagian kerja/ peran kaum pria dan wanita. Jika proses pembuatan tembikar selalu dikerjakan bersama (kaum wanita dan laki-laki), maka berbeda dengan proses pembuatan tembikar di desa tembikar yang seluruh proses diperankan oleh kaum wanita. Hal ini terjadi karena hasil penjualan tembikar tidak banyak membantu memenuhi kebutuhan sehari-hari mereka. Kaum laki-laki lebih fokus menggarap kebun yang menurut mereka lebih menjamin dan memenuhi kebutuhan ekonomi mereka. Selain itu, mereka juga ada yang berprofesi sebagai wirausaha, yaitu mendirikan kios-kios kecil yang didalamnya menjual beraneka macam kebutuhan. Tembikar didistribusikan di pasar Lohia, Montobua, dan Mabolu yang berada di daerah tersebut.

Para pengrajin tembikar di Desa Lakarinta berupaya untuk tetap melakukan tradisi pembuatan tembikar yang diturunkan oleh orang tua mereka meskipun tradisi tersebut hanya berhenti di anak mereka. Hal ini merupakan wujud dari cara mereka menghargai apa yang diturunkan oleh nenek moyang mereka. Setidaknya tradisi tersebut masih dapat dilihat oleh cucu mereka hingga saat ini walaupun tidak ikut serta melakukannya. 


\section{DAFTAR PUSTAKA}

Fairyo, Klementin. 2009. dalam Jurnal Balai Arkeologi Papua Vol. 1 No. 2, hlm 93-99. “Gerabah Situs Mansinam Kajian Etnoarkeologi”. Papua: Balai Arkeologi Papua.

Grant, Jim. 2002. The Archaeology Coursebook: An Indroduction To Study Skills, Topics and Methods. London: Routledge.

Hakim, Budianto 2011. Penelitian Prasejarah (Neolitik) Di Situs Kamansi Kalumpang, Kabupaten Maтиju. Laporan Penelitian. Makassar: Balai Arkeologi Makassar. Hasanah, Hasyim. 2016. dalam Jurnal ad_Taqddum, Volume 8. Nomor 1 Juli, hlm 2146. “Teknik-Teknik Observasi Sebuah Alternatif Metode Pengumpulan Data Kualitatif Ilmu-Ilmu Sosial”. Semarang: Lembaga Penjamin Mutu UIN Walisongo.

Kosasih, E. 1989. dalam Jurnal Berkala Arkeologi, Volume 10. No. 1 Maret, hlm 10 23. "Prospek Tradisi Pembuata Gerabah di Kampung Gonebalano Pulau Muna (Sulawesi Tenggara)”. Yogyakarta: Balai Arkeologi Yogyakarta.

Kramer, Carol. 1979. Ethnoarchaeology: Implications of Ethnography For Archaeology. New York: Columbia University Press.

McKinnon, Edwards. 1991. Buku Panduan Keramik. Jakarta: Pusat Penelitian Arkeologi Nasional.

Pojoh, Inggrid Harriet Eileen. 1981. Pelandas Banten Lama Sebuah Penelitian Pendahuluan Teknologi Gerabah. Skripsi. Depok: Universitas Indonesia.

Rahmatang, 2016. Tradisi Massuro Ma'baca Dalam Masyarakat Rompegading Kecamatan Cenrana Kabupaten Maros. Skripsi. Makassar: Universitas Islam Negeri Alauddin Makassar.

Rangkuti, dkk. 2008. Buku Panduan Analisis Keramik. Jakarta: Pusat Penelitian dan Pengembangan Arkeologi Nasional.

Sandjaja, B dan Albertus Heriyanto. 2016. Panduan Penelitian. Jakarta: Prestasi Pustaka.

Sendana, Yanirsa Abigael. 2017. Tembikar Pada Gua Kuya di Desa Pondoa Kecamatan Wiwirano Kabupaten Konawe Utara, Provinsi Sulawesi Tenggara (Kajian Bentuk dan Ragam Hias). Skripsi. Kendari: Universitas Halu Oleo. 
Soegondho, Santoso. 1995. Tradisi Gerabah di Indonesia. Jakarta: P.T. Dian Rakyat.

Soejono, R.P. \& R.Z Leirisa. 2010. Sejarah Nasional Indonesia I. Jakarta: Balai Pustaka.

Soekomo, R. 1973. Pengantar Sejarah Kebudayaan Indonesia 1. Yogyakarta: Kanisius.

Suroto, Hari. 2017. dalam Jurnal Balai Arkeologi Papua Vol. 9 No.2, hlm. 229-236. "Tradisi Pembuatan Gerabah di Desa Ngrencak, Kabupaten Trenggalek". Papua: Balai Arkeologi Papua.

Syahadat, Ray March. 2014. Pelestarian Lanskap Sejarah Kota Bau-Bau Sebagai Kota Pusaka Indonesia di Provinsi Sulawesi Tenggara. Tesis. Bogor: Institut Pertanian Bogor.

Yabu, M. Tanpa Tahun. Eksistensi Lukisan Prasejarah Pada Situs Liangkabori Kabupaten Muna Sulawesi Tenggara. Makassar: Fakultas Seni dan Desain Universitas Negeri Makassar.

KBBI, 2016. Kamus Besar Bahasa Indonesia (KBBI). [Online], available at: kbbi.kemedikbud.go.id [diakses 05 April]. 
Jurnal Arkeologi Papua Vol. 12 Edisi No. 1 / Juni 2020 : 75-94 